The need for adequate ethical guidelines for qualitative health research

\author{
A necessidade de diretrizes éticas adequadas \\ às pesquisas qualitativas em saúde
}

IaraCoelho Zito Guerriero ${ }^{1}$

Sueli Gandolfi Dallari ${ }^{2}$

${ }^{1}$ Comitêde Ética em Pesquisa, Secretaria M unicipal deSaúde deSão Paulo. Rua General Jardim 36, Vila Buarque. 01223-906. São Paulo SP. iarag@uol.com.br ${ }^{2}$ Universidade deSão Paulo.
Abstract This paper discusses adequacy as to the application of Brazilian guidelines, Resolution 196/ $96^{1}$ and complementaries to qualitative health re searches, considering that these are based on nonpositivistic paradigms. Frequently, decisions about the research are made together with the studied community. There is a concern with justice and social change. And, since subjectivity can be considered their privileged instrument, such researchers seek a balance between objectivity and subjectivity, discussing how to overcome the researcher's view. Wehavestudied theapplication and the concept of research found in international and in the Brazilian guidelines. We have noticed that they adopt a positivist conception of research, which establishes 1) the hypothesis test, 2) that all procedures are previously defined by the researcher; 3 ) neutrality of the researcher and of the knowledge produced. We will present some characteristics of qualitative research; the ethical implications in the way as qualitative research is conceived in non-positivist paradigmsand a brief history of these guidelines. Our conclusion: it is inadequate to analyze qualitative researches using these documents, and we suggest the design of specific guidelines for them.

Key words Ethics in research, Q ualitative research, $\mathrm{H}$ ealth services research, Ethics in research in Human and Social Sciences, Bioethics
Resumo 0 artigo discute a adequação de aplicar a Resolução 196/961 do Conselho Nacional de Saúde- CNS, às pesquisas qualitativas em saúde, que se baseiam em paradigmas não positivi stas. N estas pesquisas, freqüentemente as decisões sobrea pesquisa são tomadas conjuntamente com a comunidadeem estudo. Há a preocupação de favorecer a justiça e a mudança social. E, uma vez quea subjetividade podeser considerada seu instrumento privilegiado, busca-se o balanço entre objetividade e subjetividade, e discute se como superar a visão do pesquisador. Estudamos o âmbito de aplicação e a concepção de pesquisa pre sentes nas diretrizes éticas internacionais e brasileiras. Verificamos que elas adotam uma concepção positivista de pesquisa, que prevê: teste de hipótese, definição prévia detodos os procedimentos pelo pesquisador e neutralidade do pesquisador e do conhecimento produzido. Serão apresentadas algumas características das pesquisas qualitativas, as implicações éticas da maneira como a pesquisa qualitativa é concebida nos paradigmas não positivistas e um breve histórico dos documentossobreética em pesquisa. Concluímos que não é adequado analisar estas pesquisas com base nestes documentos e sugerimos a elaboração de diretrizes específicas.

Pal avras chave Ética em pesquisa, Pesquisa qualitativa, Pesquisa em serviço de saúde, Ética em pesquisa em Ciências Humanas e Sociais, Bioé tica 
H ealth researches

in Social Sciences and Humanities

The objects of study for researchers in Social Sciences and the Humanities are generally not reached by means of the methodologies used by the $\mathrm{N}$ atural Sciences. For this reason the former has been discussing epistemological and methodological matters, sincethe early ages of sciences and research education, with a view to constructing more adequate methods to deal with these objects of study.

Even when dealing with body related issues, these researches generally consider the meanings ascribed to the body, how these meanings are experienced by each person, rather than dealing with the physical body per se. By selecting another's subjectivity or therelationship between people, or even theattribution of meaning as their objects of study - to cite just a few examples -, these works cannot exclude the researcher and, instead of seeking impartiality (here understood as non-interference from the part of the researcher's subjectivity), they assume that it is impossible to exclude such subjectivity, thus becoming concerned with reaching an appropriate balance between subjectivity and objectivity - which is partially achieved by acknowledging the social placefrom which one speaks and the quality of the relationship established with the researched. In such studies, the researcher's subjectivity is, so to speak, their privileged working instrument. In this sense, we should resort to Gadamer's ${ }^{2}$ words when he states that the person who understands does not know or judge from merely facing the others without being affected by them; it is through a specific sense of belonging that binds him to the others that understanding takes place, in such a way that he is affected with them and thinks as they do.

Qualitative research has come a long and important way within the areas that compose theSocial Sciences and Humanities, and has been used with increasing frequency in the Collective H ealth field - essentially interdisciplinary. Q ualitative research is a field of investigation per se ${ }^{3,4}$. It introduces a number of complex and interrelated lexical terms into thereal $m$ of sciences. There is no paradigm to which it specifically adheres; instead, a number of subject areas and theories adopt qualitative approaches ${ }^{3}$.

Different techniques may be employed by qualitativeresearch, and these may bedivided into: data collecting techniques, data registry techniques and data analysis/interpretation techniques ${ }^{5}$. Vast literature on such techniques is available. Among those referring to data collection, onewill find: life stories, interviews, focal groups, and participant observation, to name a few. Those for data registry include: field notes, photography, audios/video recordings, etc. Theones referring to data analysis/interpretation include: discourse analysis, content analysis, among others. The combination of several techniques, empirical material, perspectives and observers in one sole study, all coherently articulated, is a strategy that adds rigor, complexity, besides enriching and deepening the research. This allows everyone to know and tell the same story from different points of view.

Often there is no hypothesis testing in qualitative research. Instead there is a search for the understanding of meaning and intention - as inseparablefrom actions, relationsand social structures ${ }^{6}$. It is thus an interpretative and naturalistic approach to seeing the world, sinceit studies things in their natural environment, seeking to make sense of phenomena or to interpret them from the meanings attributed to them by people who do things together in places where these things are habitually done. The research field consists of a group of material and interpretive practices that make this world visible in a different way ${ }^{3}$.

Qualitative research is a contextualized activity that locates the observer in the world. In texts produced from a piece of qualitative research, many differing aspects will be pictured simultaneously: different voices and points of view. Each metaphor used can be employed so as to create simultaneity, rather than a linear sequence. These texts movefrom the personal to the historical and cultural realms; they are dialogic and assume an active audience, such as readers who are invited to explore different views of a context, to diveinto it and surface with new realities to understand ${ }^{3}$.

The idea of being adopted in different paradigmsand of making use of different techniqueswhich may becombined in onesolestudy - makes it difficult for researchers to agree with one sole definition of field, simply because it is never the sole field. For this reason, we agree with N elson, as stated in Denzin and Lincoln ${ }^{3}$, adopting thefollowing definition: Qualitativeresearch is an interdisciplinary, transdisciplinary [...] field. It crosscuts the humanities and the social and physical sciences. Qualitative research is many things at same time [...] Its practitioners are sensitive to the value of the multimethod approach. They are commited to the naturalistic perspective and to the interpretative understanding of human experience. At the sametime, thefield isinherently political and shaped by multiple ethical and political positions. 


\section{Paradigms and ethics}

It is important to highlight that researchers who use qualitative methods may combine several techniques in one single study, however there is no consensus as to the possibility of used different paradigms in one single piece of research.

$M$ ethods employed to generalize, analyzeand organize data are context-bound. They are defined by an intersubjectively pre-determined background, by "truths" through which social values and ideology are expressed in research and are inscribed within theories, hypotheses and models that define the research projects. Thus, research and knowledge production are not produced by means of an individual cognitive process; they are rather social productions. Objectivity is, consequently, manifest by social relations ${ }^{7}$, much as the outsi de perception is marked by the researcher's assumptions, as argued by Bateson ${ }^{8}$ : O utside experience always experiences interference from the specific sensorial organ and from neural paths. The objects are therefore my creation, and my experience with them is subjective, not objective. [...] The two generic processes - firstly, that I am unconscious of the formation process of images that I consciously see and, secondly, that through these unconscious processes I use a number of assumptions that become inbuilt in the finished image - are, for me, the beginning of empirical epistemology.

Thus, theexplanation issupported by description that depends upon perception. This perception is, in turn, intimately related to each one's assumptions. Wethereforehighlight the relevance of scientific assumptions - paradigms - and the importance of explicating them. It is both difficult to consider a scientific production as individual, since the researcher is strongly context and time-bound, and to consider it as a mere social production, since the individual does not simply carry out what the social environment "proposes", but also re-creates this environment. In other words, the researcher collects or generates empirical material related to the matter of investigation and then analyses and writes about it, al ways from a specific interpretive community. Each community has their own historical research tradition, which constitutes a specific point of view. According to Gadamer ${ }^{2},[\ldots]$... the interpreter's belonging to their text is just like the belonging of the point of view in the perspective one confers a picture [...] someone who understands, does not arbitrarily choose their point of view; rather, they find their fixed place beforehand.
Paradigms adopted by the researcher previously definetheresearcher's placein thefield, and the quality of relationship that will beestablished with the researched group.

Thomas Kuhn ${ }^{9}$ is an important author when it comes to discussing the question of paradigms. He reports his surprise when working with social scientists and noticing the number and the extension of disagreements when it came to the nature of methods and scientific problems. Thisled him to question if practitioners of Natural Sciences had more solid or permanent answers for these questions. Henoticed that, although astronomers, physicists, chemists and biologists were not used to evoking controversies about the basis they did not have answers to these questions either - even though they did not discuss them frequently. It was the search for the reason of this difference that made him notice the role of paradigms in scientific researches, or, in his words: "[...] paradigms (are) the universally accepted scientific accomplishments that, for some time supply problems and model solutions for a community of practitioners in one given science".

Once the paradigms are established, the scientists from a given area can seek support in them and proceed in their researches, without the need to process any daily methodological discussion. In calm moments, these paradigms are unchallengeable, and facts that do not seem to fit them are often not even noticed or worthy of being noticed by researchers. However, as these anomalous events are seen, and become numerous, competing paradigms arise. A scientific revolution is, therefore, preceded by a pre-paradigmatic period, whosecharacteristic is the co-existence of several paradigms, none being hegemonic. When one of them is established as superior, the others are abandoned.

Following this reasoning, Kuhn ${ }^{9}$ states that Science takes the paths of discontinuity and ruptures, rather than that of linear growth, with continuous incorporation of new knowledge. What happens is that in post-paradigmatic period, or after each scientific revolution is processed, ruptures are hidden in the subsequent texts and with the incorporation of new paradigms; the authors start to write as if they had always been there to determine the interpretation of data. This may give the reader theimpression of continuity, which in fact did not happen. In this perspective, paradigms are incommensurable and, for this reason, it is not possiblefor oneperson to "combinethem".

Denzin and Lincoln ${ }^{10}$, in turn, consider that the paradigm is a human construction that en- 
compasses four concepts: ethics, epistemology, ontology and methodology. Ethics is the concept that "asks": How can I be a moral person in the world? Epistemology poses the questions: How do I know the world? What is the relation between the researcher and knowledge? In other words, all epistemology implies an ethical-moral position about the world and about the researcher, as assumes Christians ${ }^{11}$. Ontology poses basic questions about the nature of reality and the nature of humans in the world. And methodology focuses on the best means to obtain knowledge about the world.

However, Denzin and Lincoln ${ }^{10}$ consider that there aresituations in which it is possibleto combine paradigms. They exemplify by stating that positivist and post-positivist paradigms can be combined between them, though none of them can be combined with paradigms such as the interpretive, the post-modern critical theory, constructivism and participative inquiry. We believe that this impossibility is due to the very nature of paradigms, especially the positivist paradigms, which do not admit ambiguities or contradictions. If we take the paradigm of complexity into account ${ }^{12}$, with its assumption of co-existence and articulation between contradictions, then thedialogue would be possible.

In this paper, inspired by Kuhn's ${ }^{9}$, and Denzin and Lincoln' $\mathrm{s}^{10}$ texts, we use the term paradigm to refer to the beliefs that the researcher has and shares with their peers even before designing a research project - which includes their understanding of the world and about the human being, about the way knowledgeis produced, about how to scientifically validatetheir work, and about their role in the application of this knowledge. We believe that the assumptions guiding the researcher's work can contribute to defining how their relation with the participant will be, which has key ethical implications. And, much as Nelson and M cPherson ${ }^{13}$, we consider that in order to facilitate discussions, it is possible to establish three groups of paradigms: positivists - which include positivism and post-positivism -, interpretive which includes constructionism and hermeneutics-, and critical - which includes the critical theory and the neo-M arxism.

We consider it fundamental that the researcher should know in which paradigm they are basing their work, and, if appropriate, that they make their combinations. What seems undesirable to us is the lack of reflection about such aspects since this could lead not to a combination of paradigms, but to a confusion that may place the researcher in ambiguous situations in the research realm. It is necessary that the researcher should know their place in the field of research if they seek impartiality or if their subjectivity is assumedly present, and how it will be taken care of. This is fundamental to the definition of quality of the relationship that will be established between the researcher and the researched.

To give an example, we can say that a constructivist study - in which the researcher aims at constructing, with participants, a consensus from the many realities each one brings - is unattainable if there is no trust relationship between participants and researcher. Besides, if the researched has not fully understood what the research will beabout, they will not be in a situation to participate, which will then alter the result of the study. Thus, the competent use of this scientific method presumes respect to ethical aspects, especially in terms of previously informing participants about the research and of only conducting it after the consent from the researched group. Thus, wecan see that, in interpretive and critical paradigms, ethics is intrinsic to the research methodology.

Weconcludethat it is essential to consider the paradigms that guide each research, so that it is possible to proceed to the analysis of ethical aspects. N ext, we present the international guidelines on ethics in research - which were reference for the writing of Resolution CNS 196/96 - and we analyze their declared scope of application, as well as their research definitions, which will allow us to identify in which paradigm each one of them is situated.

\section{Standardizing documents for ethics in research with human beings}

Ethical aspects about research with human be ings have been standardized with international relevancesincethe publication of the N uremberg Code $^{14}$ in 1947 (before that, there were documents for local use in some places such as Prussia (1901) and Germany (1931), which did not, however, have international reach). The World M edical Association published the H elsinki Declaration ${ }^{15}$ in 1964 (reviewed in 1975, 1983, 1989, 1996, 2000, 2002), whose current version dates of 2004. The Council for International Organizations of M edical Sciences (CIOM S), in collaboration with the World $\mathrm{Health}$ Organization (WH O) designed, in 1991, the International Guidelines for Ethical Review of Epidemiological Studies $^{16}$, currently under revision, and the In- 
ternational Guidelines for Biomedical Research Involving H uman Beings ${ }^{17}$, of 1982 (reviewed in 1993 and 2002). These documents have broadly been promoted and, in several countries - Brazil included - they have become important reference for the design of national guidelines on ethics in research with human beings. For this paper, the cited versions of the Resolution 196/96 were analyzed.

Another document of international relevance was the Belmont Report ${ }^{18}$, published in 1979. It is the work result of the $\mathrm{National}$ Commission for the Protection of H uman Subjectsin Biomedical and Behavioral Research, set up by the government of the United States. This report presents ethical principles to be taken into account in such pieces of research, and has become a reference for a number of different documents.

We need to highlight that these documents delimit their field of application and present a definition of research that is adequate to them. The Helsinki Declaration ${ }^{15}$, for example, is designed for medical researches, and informs the reader that the "purpose of biomedical research involving human beings must be to improve the diagnostic, therapeutic and prophylactic procedures, as well as to understand the etiology and pathogenesis of the ailment."

CIOMS ${ }^{16}$ have been concerned with epidemiologic researches and consider that "research is conceived so as to produce new knowledge, which is generalizable, differing from the kind of knowledge about one single individual or a program". The Belmont Report ${ }^{18}$ adopts the term research to " $[. .$.$] design an activity that is planned$ to test a hypothesis, which allows one to reach a conclusion and develop or contribute to generalizableknowledge (expressed, for example, by theories, principles or by the establishment of relations)". Understanding assumed by this document states that the research should usually be described by a formal protocol, which presents objectives and procedures. $\mathrm{ClOM} \mathrm{S}^{17}$ were designed to assist in the definition of national policies on ethics in biomedical research, and employs the term "research" to refer to the class of activities whose objective is to develop or contribute to generalizable knowledge. Generalizable knowledge consists of a set of theories, principles and relations, or in the accumulation of information on which those theories are based, that may be confirmed by scientific methods of observation and inference accepted.

The 196/96 CNS Resolution adopts the same research concept as the 1993 17 , though the Brazil- ian norm broadens its scope to all procedure, of any nature, involving human beings, whose acceptance may not yet be established in scientific literature, will be considered research and should, therefore, follow the guidelines of this resolution. Referred procedures include, among others, those of instrumental, environmental, nutritional, educational, sociological, economical, physical, psycho or biological natures, regardless or their being pharmacological, clinical or surgical in approach and of their preventative, diagnostic or therapeutic purposes.

One can ther efore see that much as the Belmont Report ${ }^{18}$, also the CIOMS $(1982,1993)^{17}$ norm and the 196/96 ${ }^{1}$ CNS Resolution have showed, from the beginning, a biomedical concern, and all of them assume the same research paradigm. The situation with the 196/96 CNS Resolution is, however, extreme, being applied to researches that involve human beings from any epistemological area. We need to also state that the Belmont Report ${ }^{18}$, whose application scope are biomedical and behavioral researches, suggests the design of specific guidelines for social researches, as seen in the extract bel ow, taken from the Report's third footnote: Because the problems related to social experimentation may differ substantially from those of biomedical and behavioral research, theC ommission specially declinesto make any policy determination regarding such research at this time. Rather, the commission believes that the problem ought to be addressed by one of its successor bodies.

If one compares the research definition found in the 196/96 CNS Resolution with what has been discussed here about qualitative research and non-positivist paradigms, it is possibleto see that these approaches to research are very different.

\section{Characteristics of qual itative research} in the health area, which do not follow a positivist paradigm and the 196/96 Resolution: incommensurable differences

\section{Ethical aspects are intrinsic}

In positivist paradigms there is a search for non-interference from both the researcher's and the researched group's subjectivities. The search for "neuter" knowledge implies that values are considered unwanted sincethey could lead to the questioning of the study's results. In interpretive and critical paradigms, however, researcher's subjectivity is an important instrument in the 
research. It is not possible to isolate the knowledge produced from the person that produced it - which makes the researcher's reflective ability a permanent need. "[...] look at oneself; understand oneself; correct oneself, which is both a principle of thought and an ethical need"19. Ethics becomes part of the research - not an outside aspect to be separately evaluated. Ethical aspects are intrinsic to qualitative, non-positivist researches.

This does not mean that the discussion of ethical aspects in research can be forgotten. On the contrary, it must becontinuously maintained throughout the research. It is worth mentioning that the consequences of an action, even if righteous, are not totally predictable. For this reason, it is necessary to make an "ethical bet", as suggested by M orin ${ }^{19}$, assuming uncertainty, recognizing the risks and designing a strategy.

The incorporation of a strategy admits the actor's permanent vigilance during the wholeaction, considers the unexpected, modifies the strategy during the action and, eventually, stops the action if there is prejudicial deviance. The strategy remains an errant navigation in an uncertain sea, and evidently requires pertinent reasoning ${ }^{19}$.

\section{The researcher-researched relationship}

Qualitative research, often conducted by researchers in the Social and Humanistic areas, is carried out with human beings; the researched do, in fact play a role of subjects, since they "[...] are regarded and treated as people, i.e., as socialcultural entities; and not only as human beings, i.e., as biological entities [... $]^{\prime 20}$. With this concept of the researched in mind, many times the researcher defines the object of thestudy itself, as well as the strategies, with the researched. In Schmidt's ${ }^{21}$ words: The interlocutor (researched) explicitly places in the scene their need to negotiate the common and diverging interests belonging to the researcher and the group of individuals that take part in the research. This happens because the observation, the field co-existence and the interviews are concei ved as shared situations of work that must interest both sides, as process and as work. The dialogue is the vehicle used for the construction of a kind of knowledge whose authorship and ownership are also shared.

While discussing the specificities of Clinical Psychology research, Figueiredo ${ }^{22}$ considers that the result is not sought by the researcher, but is found by them, since the clinical space may be defined as the establishment of a time and place in which "the other can become and show them- selves in their otherness." Certain findings can only be made in such clinical space precisely because "and as far as the clinic provides a unique ethical experience, that of theunexpected in their irreduciblealterity". Thisisa kind of relationship that incorporates ethical aspects, since, as stated by Emmanuel Levinas, ethics implies respect for the other in their otherness; and that, on theother hand, if not adequately established, prevents the fulfillment of the research.

Anthropology has established ethnography as their own method to investigate social reality. Ethnography implies a social relation between the researched and the researcher. Ethnographers seek to establish a close relationship, one of trust, with their researched groups since this would define the quality of data. Without the establishment of this trust relationship, the research can even be void ${ }^{5}$.

In qualitative research, which operates outsidepositivist paradigms, ther lationship between researcher and researched is close, based on trust, in which differing interests are discussed in the open, and decisions about the research may be shared - including its objectives and strategies. Thus, thevery design of the research is being constructed throughout its process, in such a way that the researched is actively participating; defending their interests and is taking part in the research while it is of their interest to do so. We have therefore noticed that the principles of autonomy and beneficence, that basethe 196/96CNS Resolution are contemplated in these researches, due to their characteristics; they are compatible with their paradigm, and will be considered when it comes to peer validation.

The researched exercises their autonomy not only because they can consent to participate in a piece of research, but al so becausethey can interfere in its construction process.

\section{Informed consent}

Among researchers that adopt qualitative approaches, theimportance of presenting their work proposal to the probable researched group or individual and of including in thestudy only those who have agreed to take part in the research is unquestioned. However, the way this process of information and consent is going to occur is intimately related to the quality of relationship that the researcher intends to establish with the participant. Therefore, the free and informed term of consent must be considered in principle, but not in procedure to be followed, as per the 196/ 
96 CNS Resolution. In qualitative research, consent is procedural, which is coherent with its emerging design. The requirement that the informed consent be in written form is often not appropriate - for cultural reasons, or due to the researched conditions, such as illiteracy, or even in order to protect them - in the case of researches with people who are in conflict with the law.

\section{Scientific merit}

Scientific merit is fundamental. However, criteria to judgethem are different in differing paradigms, and must be respected. To cite just one example, Lincoln ${ }^{23}$ sought to understand how ethics would relate both with the interpersonal and the epistemological aspects. And she proposed a number of quality criteria linking epistemology and ethics, to judge the texts produced by qualitative researchers. The criteria are: (1) Introduction of researcher's point of view and judgments; (2) The fact that the researcher assumes that the researched and their speeches are quality controllers; (3) Notice the voice that is expressed in the text, or to what extent the text presents different voices; (4) The presenceof critical or self-reflective subjectivity; (5) Reciprocity observation, i.e., to what extent the relationship in the research becomes reciprocal rather than hierarchical; (6) Sacrality observation, i.e., to what extent does scientific knowledge contributeto the full development of the human being; (7) Observation of the researcher's availability to share privileges to which they have access due to their professional situation.

Thesecriteriaalso evidencethat ethical aspects are intrinsic to methodological aspects in these researches; and that it is not adequate to evaluate scientific merit by taking into account criteria from a paradigm that is strange to the project.

\section{Anonymity}

In qualitative research, the researcher usually knows the researched personally and by their names. Besides, the researched often know each other. It is the researcher's role to discuss with their researched if they wish their names to be kept a secret when the research results are published or, if they prefer to be identified.

Keeping the researched's identities secret is a very intricatetask in qualitative research, because, as wehave seen, it is contextualized and habitually cites speech excerpts. It is quite rare that the members of the researched community will not identify each other when reading the results of the publication. However, there are situations in which maintaining anonymity is essential, and the researcher actually needs to make this commitment - for example in researches about violence, drug trafficking, etc.

A procedure that is usually adopted in qualitative researches is to send the collected material, as well as the analyses carried out to the researched, requesting that they evaluate if they consider they have been adequately represented, if anonymity was sufficiently respected or if the opposite occurred: if the participant was inadequately identified, and if the study results can somehow damagethe community. Besides allowing for the researcher to confirm if they have been adequately identified or if anonymity was adequately kept, this exercise improves the quality of analysis, and allows the researched to participate in the result construction ${ }^{24}$.

M aintenance of anonymity - or lack thereof - must be carefully analyzed and decision must be jointly made by researcher and researched. It is essential that this decision be explicit for all involved.

\section{Emerging design}

Qualitative research may present an emerging design, i.e., onethat is built throughout thework, with decisions being jointly made by researcher and researched. For this reason, it is not always possibleto describeall the procedures of thestudy, presenting them in detail, in a previously conceived project, as per the 196/96 CNS Resolution. This happens because the researcher may choose to share decisions about the study with the researched, throughout the investigation.

H owever, we need to point out that this does not exempt the researcher from a previous re search project, in which their proposal is clearly defined, as well as objectives and techniques that will be used in the research because, though it is not possible to detail every step, it is still important to explicit the means by which each decision will be made, and what criteria will be followed.

\section{Conclusion}

The CNS 196/96 Resolution does not identify its support in the positivist paradigms, and states that the resolution should apply to all researches that involve human beings. Thus, the reader, and especially the ethical committees are left with the false 
impression that there is one sole way of carrying out scientific research, and to this, the resolution is applicable. This makes if difficult to identify incompatibility in theapplication of theseguidelines in concrete cases due to the diversity of paradigms involved: what is at stake is the use of a resolution that is supported by a certain paradigm to analyze a project that may be supported by another paradigm. And, as Kuhn ${ }^{9}$ said, different paradigms are incommensurable. Even authors ${ }^{13,10}$ that consider it possible to commensurate some paradigms, such as the interpretive paradigms, do not consider it possible for the establishment of a dialogue between positivist, interpretive and critical paradigms - which is our discussion.
We thus conclude that, since different researches can work with very diverse logics, it is inadequate to treat them in the same way. We think it is essential that the design of specific guide lines for researches guided by paradigms other than the positivist. Operationally speaking, it is crucial that the ethical committees, that evaluate a largenumber of researches with human beings, include researchers that adopt different paradigms and use different methodologies, and also that all the members of these committees be capable of discussing different research paradigms, stressing that, in some, the ethical aspects are intrinsic to the methodological aspects.

\section{Collaborators}

Dallari SG advised the doctorate thesis written by Guerriero ICZ and they both worked on the elaboration of this paper. 


\section{References}

1. Ministry of $\mathrm{H}$ ealth. $\mathrm{N}$ ational $\mathrm{H}$ ealth Council. Resolution number 196; of 10th October 1996, which regulates guidelines and research norms involving human beings [online]. [cited 2006 Jan 4]. Available from: http://conselho.saude.gov.br/docs/ Resolucoes/Reso196.doc

2. Gadamer HG. Verdade e M étodo I - traços fundamentais de uma hermenêutica filosófica. $5^{a}$ ed. Rio de Janeiro: Vozes; São Paulo: Universidade São Francisco; 2003.

3. Denzin N, Lincoln YS, editors. Introduction: the discipline and practice of qualitative research. In: $\mathrm{H}$ andbook of Qualitative Research. $2^{\text {nd }} \mathrm{ed}$. Thousand Oaks: Sage; 2000. p. 1-28.

4. Nunes ED. A metodologia qualitativa em saúde: dilemas e desafios. In: Barros NF, Cecatti JG, Turato ER. Pesquisa qualitativa em saúde. Campinas: UNICAM P; 2005. p. 15-24.

5. Victora CG, Knauth DR, Hassen MNA. Pesquisa qualitativa em saúde. Porto Alegre: Tomo Editorial; 2000.

6. Minayo MC. O desafio do conhecimento científico pesquisa qualitativa em saúde. 3ạa ed. São Paulo: Hucitec; Rio de Janeiro: ABRASCO; 1994.

7. Schwandt T. Three epistemological stances for qualitative inquiry - interpretativism, hermeneutics and social constructionism. In: Denzin N, Lincoln YS, editors. $\mathrm{H}$ andbook of qualitative research. $2^{\text {nd }} \mathrm{ed}$. Thousand Oaks: Sage; 2000.

8. Bateson G. M ente e natureza. Rio de Janeiro: Francisco Alves; 1986.

9. Kuhn TS. A estrutura das revoluções científicas. 5a ed. São Paulo: Perspectiva; 2000.

10. Denzin N, Lincoln YS, editors. Paradigms and perspectives in transition. In: Handbook of Qualitative Research. $2^{\text {nd }}$ ed. Thousand Oaks: Sage; 2000. p. 157162.

11. Christians CG. Ethics and politics in qualitative research. In: Denzin NK, Lincoln YS, editors. Handbook of Q ualitative Research. $2^{\text {nd }}$ ed. Thousand Oaks: Sage; 2000. p. 133-155.

12. Morin E. Introdução ao pensamento complexo. 2a ed. Lisboa: Instituto Piaget; 1995.

13. Nelson $\mathrm{CH}, \mathrm{M}$ cPherson $\mathrm{DH}$. The task for ethics review: should research ethics boards address an approach or a paradigm? N CEHR Commun 2004; $12(2): 11-22$.
14. Trials of War Criminals before the Nuremberg Military Tribunals under Control Council Law No. 10. Nuremberg, October 1946-April 1949. Washington, D.C.: U.S. G.P.O, 1949-1953. [cited 2006 Jan 04]. Available from: http://www.ushmm.org/research/ doctors/N uremberg_Code.htm

15. World Medical Association Declaration of Helsinki. Recommendation guiding physicians in biomedical research involving human subjects, 1989. In: Council for International Organizations of M edical Sciences (CIOMS) in collaboration with the World $\mathrm{Health}$ Organization (WHO). International Ethical Guidelines for Biomedical Research Involving Human Subjects. Geneva: WHO/CIOM S; 1993. p. 47-50.

16. Council for International Organizations of M edical Sciences. International Guidelines for Ethical Review of Epidemiological Studies [online]. Geneva; 1991. [cited 2005 Nov 21]. Available from: http:// www.cioms.ch/frame 1991 texts of guidelines.htm

17. Council for International Organizations of M edical Sciences. International Ethical Guidelines for Biomedical Research Involving Human Subjects. Geneva: CIOM S; 1993.

18. The National Commission for the Protection on Human Subjects of Biomedical and Behavioral Research. The Belmont Report. Washington, D.C; 1979. [cited 2004 Jan 25]. Available from: http://ohrs. od.nih.gov/mpa/belmont.php 3

19. M orin E. O M étodo 6: Ética. Porto Alegre: Sulina; 2005.

20. Caroso C. A imagem e a ética na encruzilhada das ciências. In: Victora C, Oliven RG, Maciel ME, Oro $A P$, organizadores. Antropologia e Ética - debate atual no Brasil. Niterói: EdUFF; 2004. p. 137-150.

21. Schmidt MLS. Pesquisa qualitativa, alteridades e comunidades interpretativas. Imaginário 2003; 9:57-64.

22. Figueiredo LC. Investigação em Psicologia Clínica. In: Psicologia no Brasil: direções epistemológicas. Brasília: Conselho Federal de Psicologia; 1995.

23. Lincoln YS, Guba EG. Paradigms controversies, contradictions and emerging confluences. In: Denzin NK, Lincoln YS, editors. Handbook of Qualitative Re search. $2^{\text {nd }}$ ed. Thousand Oaks: Sage; 2000. p. 163-188.

24. Guerriero ICZ. Aspectos éticos das pesqui sas qualitativas em saúde [doctorate dissertation thesis] São Paulo (SP): Faculdade de Saúde Pública/Universidade do Estado de São Paulo; 2006. 